\title{
THE NORMATIVE IRRELEVANCE OF AUSTIN'S COMMAND THEORY IN INTERNATIONAL LAW
}

\author{
Allan Munyao Mukuki* \\ Advocate of The High Court of Kenya \\ Madaraka Estate Ole Sangale Road, Po. Box 59857,00200 \\ City Square Nairobi, Kenya
}

\begin{abstract}
John Austin has been widely criticized and supported in equal measure for his bold assertion that international law is not 'real law' due to the lack of a 'sovereign'. This article explores Austin's position and analyzes it as against its veracity in relation to current legal systems; modern contemporary international law; and analysis of legal questions in the international arena. While indeed Austin's position was true about the legal systems of his time, the same cannot be transposed into the international legal system. If on the other hand the transposition is necessary, it will be shown that international law is indeed 'real law' with a somewhat real 'sovereign' just like any municipal law.
\end{abstract}

Keywords: sovereign, international law, command.

\section{Intisari}

John Austin telah banyak dikritik dan banyak dipuji mengenai pendapatnya bahwa hukum internasional bukanlah hukum yang sebenarnya karena tidak adanya penguasa. Artikel ini membahas tentang posisi Austin dan menganalisis kebenarannya sehubungan dengan sistem hukum saat ini; hukum internasional modern kontemporer; dan analisis atas pertanyaan hukum di arena internasional. Walaupun posisi Austin adalah benar tentang sistem hukum di masanya, hal tersebut tidak dapat diposisikan untuk sistem hukum internasional. Apabila penempatan tersebut diperlukan, akan terlihat bahwa hukum internasional adalah hukum yang sebenarnya, dengan semacam 'penguasa' yang sebenarnya, sama seperti hukum nasional lainnya.

Kata Kunci: penguasa, hukum internasional, kekuasaan.

\section{Pokok Muatan}

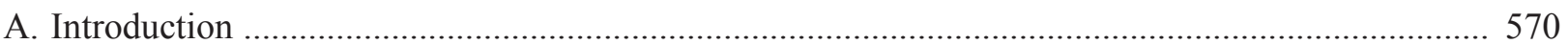

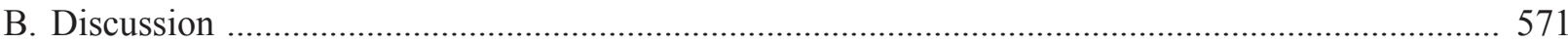

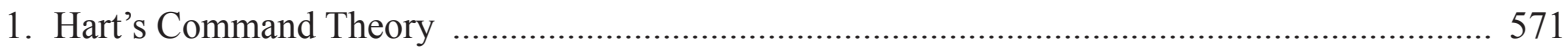

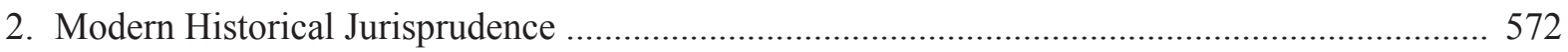

3. Modern Contemporary International Law ………............................................................... 573

4. The Concept of Sovereign at a Municipal Level ........................................................................... 574

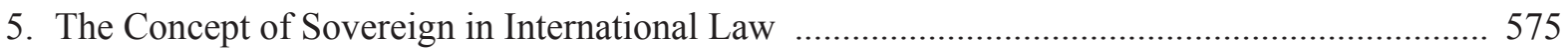

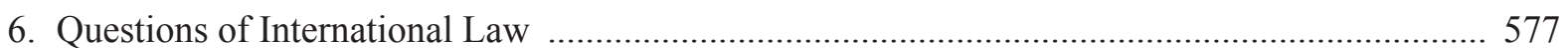

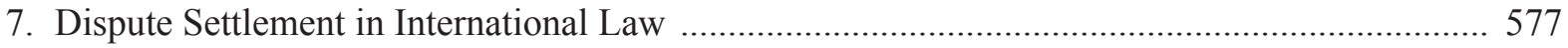

8. Practicality of Legal Questions/ Disputes in International Law ............................................... 578

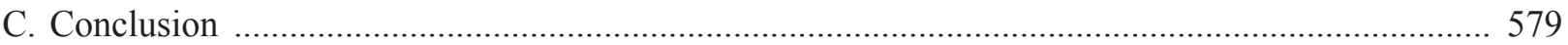




\section{A. Introduction}

John Austin through his positivist theory postulated that international law is not true law. ${ }^{1} \mathrm{He}$ took the position that international law is not really law as it has no sovereign. Austin postulated that law is a genus of command. He defined a command as "an intimation or expression of a wish to do or forbear from doing something, backed up by the power to do harm to the actor in case he disobeys." Further, he opined that 'the person to whom the command is given is under a "duty" to obey it', and the threatened harm is defined as a "sanction." This position was heavily critiqued by H.L A. Hart who was of the view that "the idea that law consists merely of orders backed by threats is inadequate to explain modern legal systems."

Moreover, since the $19^{\text {th }}$ century, there has been an ongoing controversy as to whether international law is law or not. Some arguments have been advanced that international law is positive law while others have said that international law is only a body of rules of international morality. This is a debate that this article endeavors to dissect.

Austin went on to define real law as commands of a 'sovereign.' According to him, a 'sovereign' is a person who received the arbitral obedience of the society and who in turn did not owe such obedience to anyone. By this analogy, rules of international law did not qualify as rules of positive law and not being commands of any sort, and hence were placed in a category of laws 'improperly so called'. ${ }^{4}$

This essentially questions the viability of international law as 'real-law' more so since according to Austin, international law was positive international morality only and similar to the bylaws binding a members club, ${ }^{5}$ a position that was highly criticized by Hart as will be seen below. In essence, if international law is similar to the by-laws binding a members club as postulated by Austin, this assertion could principally be read into the principle of pacta sunt servanda as found in The Vienna Convention on the Law of Treaties (VCLTT).

The VCLT is widely considered to be the most definitive authority on treaty law and practice, makes reference to pacta sunt servanda as a universal rule in its Preamble and also devotes Article 26 to its definition. ${ }^{6}$ This is also in principle drawn Article 2 (2) of the UN Charter which provides that: "All Members, in order to ensure to all of them the rights and benefits resulting from membership, shall fulfill in good faith the obligations assumed by them in accordance with the present Charter."

The good faith element of this principle suggests that States should take the necessary steps to uphold the provisions of the treaty. ${ }^{8}$ This in essence, resonates with Austin's assertion of international law being similar to the 'by-laws binding a members club'. This would mean that States can decide whether or not to exercise good faith in their upholding of international law by virtue of being 'members of the same international body, namely the UN. But again, this is pegged on the fact of the linkage with the 'command theory' to international law which is herein analyzed.

This article endeavors to analyze the context of Austin's assertion that 'international law is not real law'. This analysis will be contextualized vis-àvis the support and criticisms advanced towards the same. Further, In lieu of Austin's Command Theory, this article breaks down the theory in the realm of international law and its normative irrelevance in international law in three thematic areas: That modern historical jurisprudence discounted the force of Austin because there is no legal system

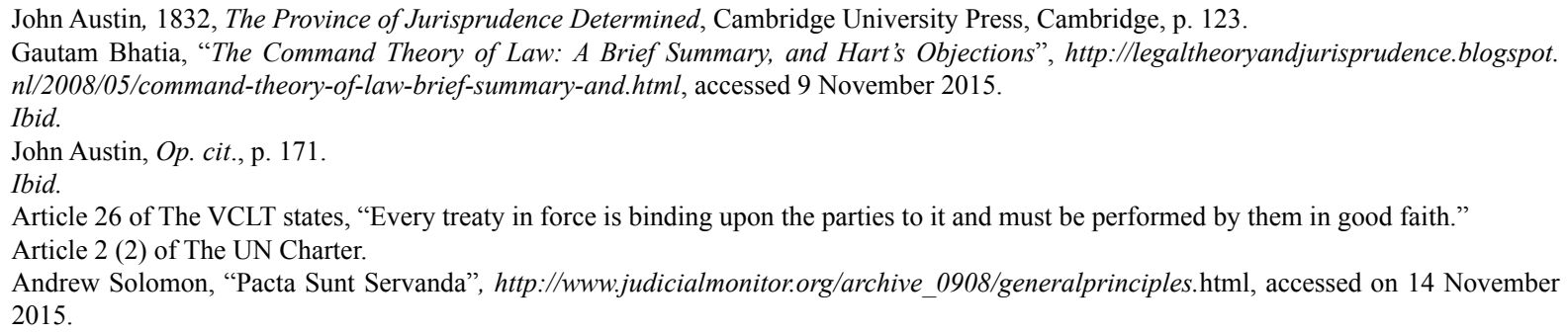


that conforms to this concept; That Austin's view has been overtaken by events more so in modern contemporary international law realm; and that questions of international law are always treated as legal questions in the international arena. These thematic analysis will caste a light on Austin's theory and show that international law is indeed 'real law'.

\section{B. Discussion}

\section{Hart's Command Theory}

John Austin, in his writings concluded that international law rules are not really law, since unlike domestic norms they are not enforced by sovereign sanctions. "The duties which international law imposes," Austin wrote, "are enforced by moral sanctions: by fear on the part of nations, or by fear on the part of sovereigns, of provoking general hostility, and incurring its probable evils, in case they shall violate maxims generally received and respected." $"$

This assertion by Austin indicates that if a law does not flow from the will of a determinate sovereign then it is not real law. It elicits the notion of "No political sovereign, no law". Hence, international law, in Austin's writings, can become positive law only under a global empire whose rulers command the obedience of all subordinate states. ${ }^{10}$

Austin's assertion on a sovereign authority in order to make a law, real law, has been met with support and criticisms alike. In supporting his assertion, some have argued that Austin is being misquoted, in that he always meant the notion of institutional authority and never the individuals who head these institutions. ${ }^{11}$ This basically entails the position that the sovereign authority that Austin speaks of, is in the institutional framework within the context of making laws e.g. Parliament- and never in the individuals who play a role within the institution in the exercise of their functions of making laws e.g. legislators. This construction seeks to separate the notion of 'individual command' from 'institutional sovereignty.'

In addition, one could take the position ${ }^{12}$ that the sovereign is best understood as a constructive metaphor to mean that it should be viewed as a reflection of a single will. ${ }^{13}$ This assertion by Harris points towards an all-inclusive view of the rules of international law. Laws should not be constructed in isolation but as a totality of the will of the people to choose representatives to represent them in the law making institutions, to make laws that they will abide by. Hence, the 'command' theory is merely a 'constructive metaphor' that indicates that rules by the institutions and the rulers are binding and obeyed as if the people willed each of the rules. ${ }^{14}$ It connotes an aspect of democracy in the sense of representation of the people, by the people, for the people. ${ }^{15}$

On the other hand, criticisms have also been advanced against his assertion. Hans Kelsen critiqued Austin's command theory and indicated that, "in many societies, it is hard to identify a "sovereign" in line with Austin's allusion. This is due to the fact that the focus on a "sovereign" makes it difficult to explain the continuity of legal systems: a new ruler will not come in with the kind

\footnotetext{
See also Harold Hongju Koh, "Why Do Nations Obey International Law?” http://digitalcommons.law.yale.edu/fss_papers/2101, accessed on 9 November 2015

10 C. Van Kuijck, "What is The Law of Nations According to John Austin", https://docs.google.com/file/d/0B2QkK3X99hLJb1ZjRXhDbmRGRjQ/ edit? $u$ sp $=$ sharing, accessed on 14 November 2015.

11 Cottrell, Rogerotterrell, 2003, The Politics of Jurisprudence: A Critical Introduction to Legal Philosophy, LexisNexis, London, p. 63. See also, Brian Bix, "John Austin: The Stanford Encyclopedia of Philosophy", http://plato.stanford.edu/archives/spr2015/entries/austin-john/, accessed on 14 November 2015.

12 See, J.W. Harris, “The Concept of Sovereign Will”, Acta Juridica Journal, Vol.II, 1979, pp. 1-15. See also, Brian Bix, Loc. cit.

13 See Brian Bix, Loc. cit.

14 William E. Conklin, 2001, The Invisible Origins of Legal Positivism: A Re-Reading of a Tradition, Kluwer Academic Publishers, New York, p. 140 .

15 "Government of the people, by the people, for the people, [...]." See Abraham Lincoln, "The Gettysburg Address Gettysburg Pennsylvania", http://www.abrahamlincolnonline.org/lincoln/speeches/gettysburg.htm, accessed on 18 November 2015.
} 
of "habit of obedience" that Austin sets as a criterion for a system's rule-maker." ${ }^{\prime 16}$ Kelsen goes further to explain the concept of continuity of legal systems in that, a legal obligation does not exist because the maker of the obligation exists, it is not tied to the person who enacted the norm. A statute, unless repealed, will remain binding even after all members of the parliament that enacted it have passed away. In the enactment of laws, legislators enact them and yet they are not explicitly familiar with their content. Hence, what explains the persistence of legal norms is the continuing existence of a system of norms of which the enacted norm has come to form a part. ${ }^{17}$

Hart on the other hand alluded to the fact that the word "command" implies a hierarchical structure of individualistic power, with law. But this assertion is not reflected in today's legal systems, as legislation often have a self-binding force. It is often said that a legislator exhibits two personalities: his legislative personality, which is tasked with giving the command, and his ordinary personality, as a citizen, which is bound to obey the commands given. Hart further argues that such a complicated device is unnecessary to explain the self-binding nature of legislation. He indicates that legislation can be viewed as a promise, which creates obligations upon the promisor. And in any event, much of legislation is done under the ambit of pre-existing rules of procedure, which bind the legislators themselves. ${ }^{18}$

In lieu of Austin's Command Theory, this paper will seek to break down the theory in the realm of international law and its normative irrelevance in international law in three thematic areas: First, modern historical jurisprudence discounted the force of Austin because there is no legal system that conforms to this concept (Modern historical jurisprudence). Second, Austin's view has been overtaken by events more so in modern contemporary international law realm (Modern contemporary international law). Third, questions of international law are always treated as legal questions in the international arena (Questions of international law).

\section{Modern Historical Jurisprudence}

Modern jurisprudence indicates no difference between communities that do not have a determinate foreign legislative authority, and that of any state with the legislative authority. In both systems, the law is enforced and observed and do not differ in its binding operation. Austin defined laws 'properly so called' as commands of a 'sovereign. ${ }^{19}$ International law according to Austin is consigned to positive morality, as it does not flow from the will of a sovereign but 'consists of opinions and sentiments current among nations'. ${ }^{20}$ Hence, according to Austin, because the rules of international law did not qualify as rules of positive law and there not being a determinate sovereign from whom the independent nations owed arbitral obedience of such rules, they did not meet the threshold of being classified as true law. $^{21}$

H.L.A Hart, the disciple of Austin in the $20^{\text {th }}$ Century era rejected the command theory of law and placed international law in a special category of 'law'. ${ }^{22}$ His rejection was based on the notion that law is the command of a legislator to a citizen backed by the threat of punishment as asserted by Austin. Austin's insistence on sanctions has led to many questions as to the essential nature of sanctions so as for a system of law to be regarded as law. The most satisfactory response to the concept of sanctions was issued by Sir Frederick Pollock who

\footnotetext{
16 Hans Kelsen,"The Pure Theory of Law and Analytical Jurisprudence”, Harvard Law Review, Vol. 55, 1941, pp. 54-66. See also, Brian Bix, Loc. cit.

17 Hans Kelsen, 1945, General Theory of Law and State, Harvard University Press, Cambridge, p. 32. See also, Lars Vink, "Austin, Kelsen, and the Model of Sovereignty: Notes on the History of Modern Legal Positivism" in Freeman and Patricia Mindus , "The Legacy of John Austin's Jurisprudence", Law and Philosophy Library, Vol. 103, p. 7.

H.L.A Hart, 1994, The Concept of Law, Clarendon Press, Oxford, p. 10. See also Gautam Bhatia, Loc. cit.

John Austin, Loc. cit.

Ibid. See also, C. Van Kuijck, Loc. cit.

Ibid., p. 171

H.L.A. Hart, Loc. cit.
} 
opined that a legal system requires the existence of a political class, and the recognition by its members of settled rules binding upon them. ${ }^{23}$

Judging by Pollock's response, international law indeed does qualify as a system of law. It satisfies all three conditions. First, there is a political community of 193 member states which are considered to be equal in the international law realm..$^{24}$ This is despite the various political, economic and cultural divisions within the various states or as George Orwell puts it in the book Animal Farm, 'all animals are equal but some animals are more equal than others. ${ }^{25}$

Secondly, there is a system of rules and principles that comprise the international legal order. The UN Charter acts as the 'Constitution' of the United Nations and Article 2 provides the key principles that the member States of the UN are to act in accordance with; principles such as good faith, sovereign equality and peaceful settlement of international disputes. ${ }^{26}$

Thirdly, the members of the international community recognize these rules and principles as binding upon them. The legally binding force of international law has been severally asserted by nations of the world for instance in an international conference, e.g. the UN Charter is grounded on the true legality of international law whereas Article 38 of Statute of the International Court of Justice (hereinafter referred to as 'the ICJ Statute') indicates that 'a function of the court is to decide in accordance with international law such disputes as are submitted to it. ${ }^{27}$

Austin perhaps confusedrules of 'international law proper' with rules of Comitas Gentium (International Comity), the latter being viewed as good will and civility founded on the moral right of each State to receive courtesy from another State. Non-observance of a rule of international law may give rise to a claim by one State against others as some kind of satisfaction whether it be diplomatic in character or whether it takes the concrete form of indemnity or reparation, its otherwise the rules of international comity. ${ }^{28}$

Besides, the binding force of international law can be traced back to the supreme fundamental principle expressed by the principles of 'pacta sunt servanda ${ }^{29}$ That is to say that agreements between States are to be respected and carried out in good faith. This principle of good faith is an absolute postulate of the international legal system and manifests itself in all rules of international law. Hence, States comply with international law for reasons other than the threat of a sanction. This means that 'international law is not binding because it is enforced, but it is enforced because it is already binding. ${ }^{30}$

\section{Modern Contemporary International Law}

In the last one century or so, a great number of international law rules have come into existence as a result of law making treaties and convention and the proportion of rules of customary international law has considerably diminished. ${ }^{31}$

This act of codification of customary international law is undertaken so as to clarify the law and promote compliance. This need for clarity is hinged on the fact that customary international law has a reputation for vagueness and ambiguity. ${ }^{32}$

\footnotetext{
J. L. Brierly, 1963, The Law of Nations, Oxford University Press, Oxford, p. 1. See also Robert Jennings and Arthur Watts, 1992, Oppenheim 's International Law, Longman, London, pp. 9-13.

24 See Article 2 (1) UN Charter. See also Case Prosecutor v Tihomir Blaskic, International Criminal Tribunal for the former Yugoslavia (ICTY), 29 October 1997, para. 40.

George Orwell, 1946, Animal Farm, Penguin Group, London, p. 112.

See, John Dugard, 1994, International Law, A South African Perspective, Juta \& Co. Ltd, Capetown, p. 9. Ibid.

28 See, Hans J. Morgenthau, "Positivism, Functionalism and International Law" AJIL, Vol. 34, 1940, p. 260. See also Louis Henkin., 1979, How Nations Behave- Law and Foreign Policy 2 ed, Columbia University Press, New York, pp. 58-63.

29 See, Article 26 VCLT. See also Article 2 (2) UN Charter.

30 See, G.G Fitzmaurice, "The Foundations of the Authority of International Law and the Problem of Enforcement", Modern Law Review, Vol.19, Issue 1, 1956, p. 1-13. See also, John Dugard, Op. cit., p. 10.

31 United Nations, 2011, Report of the International. Law Commission. Sixty-third Session 26 April-3 June and 4 July-12 August 2011, United Nations, New York, p. 15.

32 See Associated Press, "India: Airport Pat-Down Draws Protest", N.Y. TIMES, 10 December 2010.
} 
Claims that codification clarifies the law, in particular, are a myriad..$^{33}$ In principle, codification allows states to specify more precisely what customary international law requires, thereby facilitating deeper cooperation and avoiding costly disputes over vague legal rules. ${ }^{34}$ Codification also introduces the possibility of attaching compliancepromoting mechanisms - such as protocols granting international tribunals' jurisdiction over disputesto customary rules. ${ }^{35}$

Subsequently, if it be true that there is no determinate sovereign legislative authority in the international law field, the procedure for formulation of rules of international law by means of international conferences or through existing international institutions is practically as settled and efficient as any State legislative procedure. In any State's legislative procedure, the role of legislation is to stipulate rights and obligations. It lays down powers, privileges and duties. It states what can and cannot be done. The rule of law promotes good governance and stimulates development for without law, there is chaos. Hence, it is important to look at the concept of a sovereign at the municipal level as well as at the international level as against Austin's assertion and the viability of the 'command theory.'

4. The Concept of Sovereign at a Municipal

\section{Level}

In lieu of Austin's command theory, a journey back into time is necessary so as to be able to develop the link to his command theory. In the middle ages, power was always concentrated in the hands of one person (an autocrat). This autocrat was also known to be divine in that all secular and religious power was encompassed in his hands. The autocrats were considered as gods and challenging them was more or less an act of signing your own death certificate and handing it to them. Examples include the Egyptian Pharaohs and Roman Emperors. Examples of these kinds of autocrats can be deduced from the Bible in the books of Exodus and in the Gospels as well. ${ }^{36}$

Thereafter, in 1215, came the adoption of the Magna Carta ("the Great Charter"). The Magna Carta was an important document because it established the key principle that everyone is subject to the law, even the king, (emphasis added) and guarantees the rights of individuals, the right to justice and the right to a fair trial. ${ }^{37}$ This law replaced the autocratic powers of rulers to create a system of checks and balances by other leaders e.g. the legislature. ${ }^{38}$ Hence, the law placed a cap on the powers of the king in that the assembly of barons as they were known in England would check the King against excesses and as such the king was effectively below the law.

Further, the Magna Carta influenced what is now known as the two-House system in the United Kingdom - The House of Commons and the House of Lords; whose work is similar, in that they are involved in law making as well as scrutiny of the government's work. ${ }^{39}$ This bicameral approach has been adopted by various nations around the world or the unicameral approach of just one-House

33 See, R. Baxter, "Multilateral Treaties as Evidence of Customary International Law”, BYIL, Vol. XLI, 1965-1966, pp. 275-300. He argues that treaties codifying law may influence, shape, and alter the law in signatory countries). See also Richard Falk, "Reparations, International Law, and Global Justice: A New Frontier", in Pablo de Greiff, 2006, The Handbook Of Reparations, The International Center for Transnational Justice, New York, pp. 478, 480. He argues that "noting that the purpose of international law is to "codif[y] behavioral trends in state practice and shift political attitudes on the part of governments with the intention of stabilizing and clarifying expectations about the future". See also Bing Bing Jia, "The Relations Between Treaties and Custom”, Chinese Journal of. International Law, Vol. 9, Issue 1, 2010, p.108. He argues that "Noting that the purpose of international law is to "codify international law [...]". See also Hers Lauterpacht, "Codification and Development of International Law", Am. J. Int'l L., Vol. 16, 1955, p.19. He argues that "noting that the purpose of international law is to codify behavioral trends in state practice and shift politic of international law." See also Scobbie I., "The Invocation of Responsibility for the Breach of 'Obligations Under Peremptory Norms of General International Law”, Eur. J. Int'l L., 2002.

34 Meyer T., "Codifying Custom”, University of Pennsylvania Law Review, Vol. 160, 1995, p. 100.

35 Ibid.

36 Theweakerparty, "The Legislature- Definition and Historical Background", http://theweakerparty.wikispaces.com/The+Legislature++Definit ion + and + Historical + Background, accessed 8 December 2015.

37 British Library, "Magna Carta: An Introduction", http://www.bl.uk/magna-carta/articles/magna-carta-an-introduction, accessed 8 December 2015 .

38 Ibid.

39 Parliement United Kingdom, “The Two-House System”, http://www.parliament.uk/about/how/role/system/, accessed on 8 December 2015. 
system conducting both the legislation and scrutiny of governmental powers.

This analysis can also be drawn to the development of customary laws as they existed in the numerous communities of the world and this historical development is as long as the history of human kind. ${ }^{40}$ In those early times where there was no codified law by institutionalized organs of the state, people were governing themselves in a certain way and based on the cultures and customs of the communities that they came from. ${ }^{41}$ It must be noted that for thousands of years, customary and private legal systems alone regulated human activities. The obligation to behave in a certain way in a particular community became a customary law in that particular community the failure to observe result in a sort of sanction from the community against the deviant. ${ }^{42}$ This is so because behind customary law there is moral force to behave in a certain way. They became compulsory and have acquired the force of law with respect to the place or subject matter to which it related..$^{43}$

Hence, the history as discussed above, paints a picture of what Austin was suggesting, in that the idea of a sovereign from whom the laws flow and the citizens have to obey them. But on the other hand, Hart's criticism of Austin's command theory 'holds more water' in that, as seen from the era of the Magna Carta and even development of customary laws, the 'sovereign' in as much as 'he' had the power to make laws, he was also bound by the same laws and was not above them.

Hence, in unpacking Hart's position: the executive in all its functions is checked by the legislature and the judiciary against excesses in its powers; the legislature on the other hand is checked by the judiciary and the executive against excesses. This in essence over-rules Austin's postulation of a 'sovereign' who is all 'powerful' and does not have to answer to anyone.

\section{The Concept of Sovereign in International Law}

International law which is also referred to as the law of nations, is a body of varied laws, norms and customs that apply between States and other international legal personalities recognized as international actors. ${ }^{44}$

International law does not have an enforcing entity or as Austin put is, a 'sovereign' and it is wholly a voluntary endeavor by States. ${ }^{45}$ This is a concept that has been adjudicated by the Permanent Court of International Justice (hereinafter referred to as 'PCIJ') in the Lotus case, where the court stated that:

International law governs the relations between independent States. The rules of law binding upon States therefore emanate from their own free will as expressed in Conventions or by usages generally accepted as expressing principles of law [...] Restrictions upon the independence of States cannot therefore be presumed. ${ }^{46}$

Moreover, enforcement power in international law only exists when States consent to be bound by an agreement e.g. treaties are considered to be binding as between States that conclude them. ${ }^{47}$ Further, international law is a stand-alone system which is not under the legal orders of States. It is different in a number of ways: For instance, The UN Charter in its Preamble sets the main objective of the United Nations which is aimed at establishing

\footnotetext{
40 Abdo M. And Abegaz G., "Theories and history of Customary law", http://www.abyssinialaw.com/study-on-line/item/449-theories-andhistory-of-customary-law, accessed on 14 November 2016.

44 See, Encyclopedia Britannica, "International Law", http://www.britannica.com/topic/international-law, accessed on 9 December 2015. See also HG.org, "Legal Resources, International Law", http://www.hg.org/international-law.html, accessed on 9 December 2015. United Nations, "Uphold International Law", http://www.un.org/en/sections/what-we-do/uphold-international-law/, accessed on 9 December 2015.

46 See Case S.S. "Lotus” (France v Turkey, Judgment), Permanent Court of Int'1 Justice, ser.A No.10, 1927, para. 44.

47 Article 2 (1) (a) Vienna Convention on the Law of Treaties. See also, Prosecutor v Tihomir Blaskic, International Criminal Tribunal for the former Yugoslavia (ICTY), 1997.
} 
conditions under which respect and good faith must be exercised in relation to obligations arising from treaties and other sources of international law. ${ }^{48}$

The objective of the UN Charter as mentioned is enforced in a number of ways e.g. through courts, tribunals, multilateral treaties - and by the Security Council, which can approve peacekeeping missions, impose sanctions, or authorize the use of force when there is a threat to international peace and security. ${ }^{49}$ In essence, the UN Charter stands out as a representative of international law in general. A reading of Chapter XVI, Article 103 of the United Nations Charter, provides that the obligations under the UN Charter overrides the terms of any other treaty. Further, its Preamble affirms establishment of the obligations out of treaties and source of international law. This is anchored by the fact that Article 38 (1) of the ICJ Statute recognizes international conventions as sources of law and the UN Charter rightfully falls under this categorizations, thereby making it a representative of international law per se.

Moreover, Austin's assertion of international law not being 'real law' because of the lack of a 'sovereign' may be true to some extent but on the other hand an analysis of this is necessary to deduce the truthfulness of his assertion. As extrapolated above, the will/consent of States is the basis of international law as a basis for obligations of States. This is explicit for treaties which States have to consent to be bound to and it is implicit as well for customary international law with which States through consensus agree to be bound. ${ }^{50}$

The General Assembly of the United Nations, which consists of representatives of some 193 States, elicits a lot of similarity to the legislature but, it does not have powers to issue binding laws and instead it issues resolutions that serve only as recommendations. This may only be different in the aspect of internal matters of the UN, such as determining the UN budget with which it can issue binding resolutions in relation to its staff members. ${ }^{51}$

Further, to some extent, international law lacks an enforcement jurisdiction on cases before it. ${ }^{52}$ The ICJ's jurisdiction in contentious cases is hinged on the consent of only the states involved. ${ }^{53}$

There is no international police force or an established mechanism of law enforcement, as well as no supreme executive authority. The Security Council can request for military action for the enforcement of peace and security but this is hinged on the fact that there must be a prior act of aggression or the threat of such an act. ${ }^{54}$ Moreover, any such enforcement action can be vetoed by any of the Council's permanent members. ${ }^{55}$

Hence, as analyzed, international law lacks a proper 'sovereign' authority to enforce it. But on the other hand, aspects of 'sovereign power' can be traced to certain provisions of the UN Charter. Article 5 of the UN Charter provides that the Security Council can suspend a member from the United Nations if preventive measures have been taken by the Council against such a member. Further, members that violate the obligations of the UN Charter may have non-military sanctions ${ }^{56}$ imposed on them or military action enforced on them. ${ }^{57}$

The Security Council powers as indicated

49 Article 41 and 42 of the UN Charter, which is considered an international treaty that is binding among member States; See also, United Nations, "Definition of key terms used in the UN Treaty Collection", https://treaties.un.org/Pages/overview.aspx?path=overview/definition/ page1_en.xml, accessed on 14 November 2015 .

50 Article 38 (1) of the Statute of the ICJ. See also Cassese A., 2005, International Law, Oxford University Press, Oxford, pp. 153-212. See Shaw Malcom N., 2008, International Law, Grotius Publications Ltd, Cambridge, pp. 69-128.

51 Effect of awards of compensation made by the UN Administrative Tribunal in Advisory Opinion International Court of Justice 13 July 1954. See also, Encyclopedia Britannica, Op. cit

52 Certain Expenses of the United Nations see in article 17, paragraph 2 of the Charter. See also Advisory Opinion, International Court of Justice, 20 July 1962. See also, Encyclopedia Britannica, Loc. cit.

3 Article 59 of the Statute of the ICJ.

Article 42 of the UN Charter.

Article 23 of the UN Charter.

Article 41 of the UN Charter.

Article 42 of the UN Charter. 
could be deduced to mean 'sovereign' sanctions and hence opposing Austin's view that international law lacks a proper 'sovereign' that can provide sanctions. As rightfully put by H.L.A Hart, a legislator always exhibits two personalities: his legislative personality, which is tasked with giving the command, and his ordinary personality, as a citizen, which is bound to obey the commands given.

In this case, States that become members of the United Nations exhibit two personalities as well, the legislative personality that produces nonbinding resolutions in international conferences; and the ordinary personality in that by virtue of voluntarily becoming members of the UN, States are bound to respect the objectives of the UN Charter of maintaining international peace and security of which the Security Council is tasked as the 'Sovereign' of ensuring adherence to the same. ${ }^{58}$

Hence, Austin's insistence on a 'Sovereign' as discussed earlier cannot be deduced in any municipal legal system, apart from what was known as the Middle Ages. Municipal legal systems indeed have a sovereign in the name of the executive, but even the so called sovereign is bound by the laws that it creates and hence as it makes laws, so it must abide by them or as the English philosophers rightfully put it, 'As you make your bed, so you must lie on it.' The same concept applies to the international legal system, inasmuch as States are equally sovereign, ${ }^{59}$ they must abide by the objectives of the United Nations once they become members and the same applies to non-members too. ${ }^{60}$ They must adhere to the rules in good faith, ${ }^{61}$ failure to which sanctions may be imposed on them by the 'Sovereign' mandated to do so (Security Council). It must be noted that members of the Security Council are also members of the United
Nations and they are also bound by the objectives of the United Nations Charter.

\section{Questions of International Law}

John Austin compared international law to a system of by-laws that bind a members club. ${ }^{62}$ This was premised on the fact that international law has no 'real' sovereign' but as analyzed in this article, the system propounded by Austin was one that existed in the Middle Ages and no longer exists now.

A further counter-argument against Austin's assertion that international law is not real law $^{63}$ is that in any system of law in the world, questions of international law are always treated as legal questions in the international arena. A brief analysis of this will be undertaken so as to show how international law has dealt with the issue of 'questions of international law'.

\section{Dispute Settlement in International Law}

Article 33 (1) of the UN Charter for provides the various dispute settlement mechanisms which include negotiation, enquiry, mediation, conciliation, arbitration and judicial settlement. Article 94 (1) of the Charter further provides for the compliance with the decisions of the ICJ by the State parties involved in it as also provided for in Article 59 of the Statute of the ICJ.

It must be noted further that the law applied in judicial determination of disputes is international law and not domestic law. This supports the assertion that questions of international law are always treated as questions of law in the international judicial mechanisms. The International Criminal Tribunal for the former Yugoslavia (hereinafter referred to as 'ICTY') in the Blaskic case ${ }^{64}$ stated that:

The Appeals Chamber wishes to emphasize at the outset that the Prosecutor's reasoning,

\footnotetext{
58 See, Articles 2 (5); Article 5, Article 11 (3), Article 12, Article 24, Article 25, Article 26, Article 33, Article 36, Article 37, Article 39, Article 41, Article 42 of the UN Charter.

Article 2 (1) of the UN Charter.

60 Article 2 (6) of the UN Charter.

Article 26 of the Vienna Convention on the Law of Treaties. See also Article 2 (2) of the UN Charter.

John Austin, Op. cit., p. 171.

Ibid.

64 See Case Prosecutor v Tihomir Blaskic, International Criminal Tribunal for the former Yugoslavia (ICTY), 29 October 1997, para. 40.
} 
adopted by the Trial Chamber in its subpoena decision is clearly based on what could be called "the domestic analogy" $[. .$.$] Hence, the$ transposition into the international community of legal institutions constructs or approaches prevailing in national law may be a source of great confusion and misapprehension. In addition to causing opposition among States, it could end up blurring the distinctive features of international courts.

To adopt the tribunal's reasoning into my analysis, basically the court was of the view that domestic laws cannot be transposed into international law as this would lead to endless conflicts between States and in essence convert international courts into 'domestic courts' of some sort. Hence, the tribunal was in principle creating a demarcation between domestic and international law and the fact that disputes between States should be dealt with by international law and not their individual domestic laws.

The decision by the Appeals Chamber of the ICTY confirms the assertion that discounts Austin's position that international law is not real law. The tribunal in principle was confirming the existence of international law.

Article 38 (1) of the Statute of the ICJ further firms up the existence of international law by providing the sources of international law: international conventions; international customs, general principles of law and judicial decisions as well as teachings of the most highly qualified publicists. Hence, as envisaged by the ICJ Statute, indeed, international law does exist and the same can be deduced from within the international law framework to prove its own existence.

\section{Practicality of Legal Questions/ Disputes in International Law}

The matter of legal questions/disputes before international courts has produced consistent results time and time again, confirming that indeed legal questions in international law are dealt with within the realm of international legal system.

In the Mavrommatis Palestine Concessions case, the PCIJ gave a broad definition of what a legal dispute is:

A dispute is a disagreement on a point of law or fact, a conflict of legal views or of interests between two persons. ${ }^{65}$

In another case, the ICJ referred to 'a situation in which the two sides held clearly opposite views concerning the question of the performance or nonperformance of certain treaty obligations. ${ }^{96}$ The International Arbitral Tribunal in Texaco v. Libya referred to a 'present divergence of interests and opposition of legal views'. ${ }^{67}$

International Centre for Settlement of Investment Disputes (hereinafter referred to as 'ICSID') tribunals have also adopted similar descriptions of 'disputes', often relying on the PCIJ's and ICJ's definitions. ${ }^{68}$ Hence, it is deduced that the existence of a legal dispute of an international character must be accompanied by some communication which demonstrates the existence of opposing international demands and denials between States. This what the PCIJ postulated in Mavrommatis when it referred to a 'conflict of legal views or of interests between two persons'. ${ }^{69}$

Further, in the Northern Cameroons Case, the Court was of the view that "Whether there exists an international dispute is a matter for objective

\footnotetext{
See The Case Mavrommatis Palestine Concessions (Greece v. Great Britain) Ser.A. No.2 at 11, 30 August 1924.

66 Interpretation of the Peace Treaties with Bulgaria, Hungary and Romania, Advisory Opinion of ICJ.

67 See The Case Texaco Overseas Petroleum Company and California Asiatic Oil Company v. Libyan Arab Republic, Preliminary Award of 27 November 1975, 53 ILR 389, at 416 (1979).

68 Case Maffezini v. Spain, Decision on Jurisdiction of 25 January 2000, 40 ILM 1129, at para. 93, 94; Case Tokios Tokeles v. Ukraine, ICSID Case No. ARB/02/18, Decision on Jurisdiction of 29 April 2004, at para. 106, 107; Case Lucchetti v. Peru, ICSID Case No. ARB/03/4, Award of 7 February 2005, at para. 48; Case Impregilo v. Pakistan, ICSID Case No. ARB/03/3,Decision on Jurisdiction of 22 April 2005, at para. 302, 303; Case AES v. Argentina, ICSID Case No. ARB/02/17, Decision on Jurisdiction of 26 April 2005, at para. 43; Case El Paso Energy Intl. Co. v. Argentina, ICSID Case No. ARB/03/15, Decision on Jurisdiction of 27 April 2006, at para. 61; Case Suez, Sociedad General de Aguas de Barcelona S.A., and InterAguas Servicios Integrales del Agua S.A. v. Argentina, ICSID Case No. ARB/03/17, Decision on Jurisdiction of 16 May 2006, at para. 29; Case M.C.I. v. Ecuador, ICSID Case No. ARB/03/6, Award of 31 July 2007, at para. 63.

69 Schreuer C, "What is A Legal Dispute?", in Buffard, et al., 2008, International Law between Universalism and Fragmentation. Festschrift in Honour of Gerhard Hafner, Koninklijke Brill New York, p. 965.
} 
determination" and a dispute exists if a situation has arisen "in which the two sides hold clearly opposite views concerning the question of the performance or non-performance of certain treaty obligations." 70 The Court has maintained this view in other cases as well. ${ }^{71}$

Hence, from the foregoing analysis, a legal dispute in international law is one which annihilates Austin's, assertionagainst the validityofinternational law. His grounding is rather a confounding one since he did not provide a foundation upon which his assertion could be based. The aspect of a sovereign as analyzed there before has no bearing even within the domestic legal system let alone international law. Hence, the international judicial systems have also time and time again proven the existence of an international legal dispute settlement mechanism within international law.

\section{Conclusion}

John Austin in his book, 'The Province of Jurisprudence Determined'72, goes to great lengths to establish what is known as the "command theory'; in that a law is only true law if it has a true 'sovereign' to enforce it and the 'sovereign' is not bound by the law.

This assertion has been meticulously dissected by various critics and supports alike who have taken different views as to what Austin really meant. Some have taken the position that Austin meant the totality of the law making institution as the 'sovereign' and not individualistic power, while others have said that his assertion should be taken to connote democracy, 'law of the people, for the people and by the people.'

The support for Austin's assertion is by no means easy to ignore. But on the other hand, Hart came forth and stated that the 'command theory' is an illusion. He stated that there exists no legal system as suggested by Austin. This is because in as much as for instance, legislators are tasked with the duty of creating laws, they are bound to obey them. Basically, no one is above the law, even the 'sovereign' 'himself'.

Kelsen also critiqued Austin and indicated that if the 'sovereign' holds the command powers, then this would essentially mean that, should the sovereign die, the law 'dies' as well. Hence, Kelsen went further to indicate that the law as we know it exists in a system of continuity. It is a constant and even if the 'sovereign' dies, the law continues to exist as a constant unless repealed. Kelsen's position was basically that the notion of the 'sovereign' making the law and not obeying it as a totality was misconceived as this would essentially mean that with the advent of a new 'sovereign', the laws will have to change which is not the case in any legal system.

Austin's position has further been discounted by the fact that no system conforms to his 'command theory.' Hart went forth to analyze the aspect of sanctions as a 'sovereign' tool to ensure obedience to the law. The aspect of sanctions has its grounding in international law as well as in domestic law and as Fitzmaurice puts it, 'international law is not binding because it is enforced; it is enforced because it is binding. ${ }^{73}$

Furthermore, in my analysis I have asserted to the fact that Austin's assertion has been overtaken by time in modern contemporary legal systems. If it was in the Middle Ages, the 'command theory' by a 'sovereign' would have explicitly made sense as envisaged by the powers held by the pharaohs and roman leaders. But that has changed over time and the 'sovereign' themselves are under an obligation to obey the powers that they enact. No one is above the law. The same concept applies in international law as well, in that for instance, States have a duty

\footnotetext{
70 Case concerning the Northern Cameroons (Cameroon v. United Kingdom), Preliminary Objections, Judgment of 2 December 1963 , 1963 ICJ Rep. 15 , at 27

Interpretation of Peace Treaties Case, International Court of Justice, Rep. 65, at 74, 1950.

John Austin., Loc. cit.

See, G.G Fitzmaurice., Loc. cit.; See also, John Dugard, Op. cit., p. 10.
} 
to honor treaties in good faith as well as ensure compliance with their international obligations under the UN Charter and any violation of the same may lead to sanctions under international law. This in essence shows that international law and domestic laws are not different in any way, they are similar for every purpose and intent save for their subjects.

In addition, just as legal questions in domestic legal systems are handled by domestic courts using domestic laws; legal questions in international law are handled by international legal systems using international law. The similarity is glaringly similar to ignore as to the existence of international law as a 'proper law'.

In summation, Austin's assertion is important in that is helps firm up the foundation on which international law rests upon as a proper system on law. International law is indeed true law, not just for the sake of it, but to allude to Austin's terms, 'it has a sovereign and it is not similar to the by-laws of a member's club. It is the 'law of nations' as Jeremy Bentham puts it. ${ }^{74}$

\section{REFERENCES}

\section{A. Books}

A., Cassese, 2005, International Law, Oxford University Press, Oxford.

Austin, John, 1832, The Province of Jurisprudence Determined, Cambridge University Press, Cambridge.

Brierly, J. L. , 1963, The Law of Nations, Oxford University Press, Oxford.

Conklin, William E., 2001, The Invisible Origins of Legal Positivism: A Re-Reading of a Tradition, Kluwer Academic Publishers, New York.

Cottrell, Rogerotterrell, 2003, The Politics of Jurisprudence: A Critical Introduction to Legal Philosophy, LexisNexis, London.

Dugard, John, 1994, International Law, A South African Perspective, Juta \& Co. Ltd, Capetown.

Hart, H.L.A., 1994, The Concept of Law, Clarendon Press, Oxford.

Henkin, Louis, 1979, How Nations Behave-Law and Foreign Policy 2 ed, Columbia University Press, New York.

Kelsen, Hans, 1945, General Theory of Law and State, Harvard University Press, Cambridge. N., Shaw Malcom, 2008, International Law, Grotius
Publications Ltd, Cambridge.

Watts, Arthur, 1992, Oppenheim's International Law, Longman, London.

Orwell, George, 1946, Animal Farm, Penguin Group, London.

United Nations, 2011, Report of the International. Law Commission. Sixty-third Session 26 April-3 June and 4 July-12 August 2011, United Nations, New York.

\section{B. Anthologies}

Bentham, Jeremy, "An Introduction to the Principles of Morals and Legislation”, in J.H. Burns and H.L.A. Hart, 1970, The Collected Works of Jeremy Bentham: An Introduction to The Principle of Morals and Legislation, London. C., Schreuer, "What is A Legal Dispute?", in Buffard, et al., 2008, International Law between Universalism and Fragmentation. Festschrift in Honour of Gerhard Hafner, Koninklijke Brill New York.

Falk, Richard, "Reparations, International Law, and Global Justice: A New Frontier", in Pablo de Greiff, 2006, The Handbook Of Reparations, The International Center for Transnational Justice, New York.

\footnotetext{
74 Jeremy Bentham, “An Introduction to the Principles of Morals and Legislation”, in J.H. Burns and H.L.A. Hart, 1970, The Collected Works of Jeremy Bentham : An Introduction to The Principle of Morals and Legislation, London, p. 100. See also, C. Kenny, "Jeremy Bentham, Principles of International Law", http://www.classicsofstrategy.com/2015/08/principles-of-international-law-bentham.html\#1 , accessed 14 November 2015
} 


\section{Journal Articles}

Associated Press, "India: Airport Pat-Down Draws Protest", N.Y. TIMES, 10 December 2010.

Baxter, R., "Multilateral Treaties as Evidence of Customary International Law", BYIL, Vol. XLI, 1965-1966.

Fitzmaurice, G.G., "The Foundations of the Authority of International Law and the Problem of Enforcement", Modern Law Review, Vol.19, Issue 1, 1956.

Freeman and Mindus, Patricia, "The Legacy of John Austin's Jurisprudence", Law and Philosophy Library, Vol. 103.

Harris, J.W., "The Concept of Sovereign Will”, Acta Juridica Journal, Vol.II, 1979.

I., Scobbie, "The Invocation of Responsibility for the Breach of 'Obligations Under Peremptory Norms of General International Law", Eur. J. Int'l L., 2002.

Jia, Bing Bing, "The Relations Between Treaties and Custom", Chinese Journal of. International Law, Vol. 9, Issue 1, 2010.

Kelsen, Hans, "The Pure Theory of Law and Analytical Jurisprudence", Harvard Law Review, Vol. 55, 1941.

Lauterpacht, Hers, "Codification and Development of International Law”, Am. J. Int'l L., Vol. 16, 1955.

Morgenthau, Hans J., "Positivism, Functionalism and International Law" AJIL, Vol. 34, 1940.

T., Meyer , "Codifying Custom", University of Pennsylvania Law Review, Vol. 160, 1995.

\section{Internet Articles}

Bhatia, Gautam, "The Command Theory of Law: A Brief Summary, and Hart's Objections", http://legaltheoryandjurisprudence.blogspot. nl/2008/05/command-theory-of-law-briefsummary-and.html, accessed 9 November 2015.

Bix, Brian, "John Austin: The Stanford Encyclopedia of Philosophy", http://plato.stanford.edu/ archives/spr2015/entries/austin-john/ accessed on 14 November 2015.
British Library, "Magna Carta: An Introduction", http://www.bl.uk/magna-carta/articles/ magna-carta-an-introduction, accessed 8 December 2015.

Encyclopedia Britannica, "International Law", http://www.britannica.com/topic/international-law, accessed on 9 December 2015.

HG.org, "Legal Resources, International Law", http://www.hg.org/international-law.html, , accessed on 9 December 2015.

Kenny, C., "Jeremy Bentham, Principles of International Law", http://www.classicsofstrategy.com/2015/08/principles-ofinternational-law-bentham.html\#1, accessed 14 November 2015.

Koh, Harold Hongju, "Why Do Nations Obey International Law?" http://digitalcommons. law.yale.edu/fss_papers $/ 2101$, accessed on 9 November 2015.

Kuijck,C.Van,"WhatisTheLaw of NationsAccording to John Austin", https://docs.google.com/file/ d/OB2QkK3X99hLJb1ZjRXhDbmRGRjQ/ edit? usp $=$ sharing, accessed on 14 November 2015.

Lincoln, Abraham, "The Gettysburg Address Gettysburg Pennsylvania", http://www.abrahamlincolnonline.org/lincoln/speeches/ gettysburg.htm, accessed on 18 November 2015.

M., Abdo, and G., Abegaz, "Theories and history of Customary law", http://www.abyssinialaw. com/study-on-line/item/449-theories-andhistory-of-customary-law, accessed on 14 November 2016.

Parliement United Kingdom, "The Two-House System", http://www.parliament.uk/about/ how/role/system/, accessed on 8 December 2015.

Solomon, Andrew, "Pacta Sunt Servanda", http:// www.judicialmonitor.org/archive_0908/ generalprinciples.html, accessed on 14 November 2015.

Theweakerparty, "The Legislature- Definition and Historical Background", http:// 
theweakerparty.wikispaces.com/The + Legisl ature ++ Definition + and + Historical + Backgr ound, accessed 8 December 2015.

United Nations, "Uphold International Law", http:// www.un.org/en/sections/what-we-do/upholdinternational-law/, accessed on 9 December 2015.

United Nations, "Definition of key terms used in the UNTreatyCollection", https://treaties.un.org/ Pages/overview.aspx? path $=$ overview/ definition/page1_en.xml, accessed on 14 November 2015.

\section{E. Regulations}

Viena Convention of The Law of Treaties.

UN Charter.

\section{F. Cases}

Case Prosecutor v Tihomir Blaskic, International Criminal Tribunal for the former Yugoslavia (ICTY), 29 October 1997, para. 40.

Case S.S. "Lotus" (France v Turkey, Judgment), Permanent Court of Int'1 Justice, ser.A No.10, 1927, para. 44.

Case Mavrommatis Palestine Concessions (Greece v. Great Britain) Ser.A. No.2 at 11, 30 August 1924.

Case Texaco Overseas Petroleum Company and California Asiatic Oil Company v. Libyan Arab Republic, Preliminary Award of 27 November 1975, 53 ILR 389, at 416 (1979).
Case Maffezini v. Spain, Decision on Jurisdiction of 25 January 2000, 40 ILM 1129, at para. 93, 94.

Case Tokios Tokelès v. Ukraine, ICSID Case No. $\mathrm{ARB} / 02 / 18$, Decision on Jurisdiction of 29 April 2004, at para. 106, 107.

Case Lucchetti v. Peru, ICSID Case No. ARB/03/4, Award of 7 February 2005, at para. 48.

Case Impregilo v. Pakistan, ICSID Case No. $\mathrm{ARB} / 03 / 3$,Decision on Jurisdiction of 22 April 2005, at para. 302, 303.

Case AES v. Argentina, ICSID Case No. ARB/02/17, Decision on Jurisdiction of 26 April 2005, at para. 43.

Case El Paso Energy Intl. Co. v. Argentina, ICSID Case No. ARB/03/15, Decision on Jurisdiction of 27 April 2006, at para. 61.

Case Suez, Sociedad General de Aguas de Barcelona

S.A., and InterAguas Servicios Integrales del Agua S.A. v. Argentina, ICSID Case No. $\mathrm{ARB} / 03 / 17$, Decision on Jurisdiction of 16 May 2006, at para. 29.

Case M.C.I. v. Ecuador, ICSID Case No. ARB/03/6, Award of 31 July 2007, at para. 63.

Case concerning the Northern Cameroons (Cameroon v. United Kingdom), Preliminary Objections, Judgment of 2 December 1963, 1963 ICJ Rep. 15, at 27.

Interpretation of Peace Treaties Case, International Court of Justice, Rep. 65, at 74, 1950. 